\title{
HUBUNGAN TINGKAT PENGETAHUAN TERHADAP SIKAP MASYARAKAT PADA ORANG DENGAN GANGGUAN JIWA
}

\author{
Asriani $^{1)}$, Fathra Annis Nauli ${ }^{2)}$, Darwin Karim ${ }^{3)}$ \\ ${ }^{1,2,3}$ Fakultas keperawatan Universitas Riau \\ Email: Asrianineni28@gmail.com
}

Diterima: November 2020, Diterbitkan: Desember 2020

\begin{abstract}
ABSTRAK
Orang dengan gangguan jiwa adalah seseorang yang mengalami gangguan dalam pikiran, perilaku dan perasaan yang termanifestasi dalam bentuk sekumpulan gejala serta menimbulkan hambatan dalam menjalankan fungsinya. Orang dengan gangguan jiwa masih mendapatkan diskriminasi, cemooh, dijauhi, diabaikan, dikucilkan dan dianggap aib di masyarakat. Perlakuan ini disebabkan kurangnya pengetahuan masyarakat terhadap orang dengan gangguan jiwa. Penelitian ini bertujuan untuk mengetahui hubungan tingkat pengetahuan terhadap sikap masyarakat pada orang dengan gangguan jiwa dengan desain penelitian deskriptif korelasi. Sampel penelitian adalah 99 responden yang diambil berdasarkan kriteria inklusi dengan menggunakan teknik cluster sampling. Alat ukur yang digunakan adalah lembar kuesioner yang telah di uji validitas dan reliabilitas. Analisa yang digunakan adalah analisa univariat untuk mengetahui distribusi frekuensi dan bivariat menggunakan uji chi square. Hasil penelitian menunjukkan dari 99 responden yang memiliki tingkat pengetahuan baik sebanyak 64 responden $(64,4 \%)$, responden yang memiliki sikap positif sebanyak 55 responden $(55,5 \%)$. Hasil uji statistik diperoleh nilai $p$ value $=0,000<\alpha(0,05)$, maka Ho ditolak, sehingga dapat disimpulkan bahwa terdapat hubungan yang signifikan antara tingkat pengetahuan terhadap sikap masyarakat pada orang dengan gangguan jiwa. Disarankan untuk masyarakat agar dapat meningkatkan pengetahuan sehingga memiliki sikap yang positif kepada orang dengan gangguan jiwa.
\end{abstract}

Kata Kunci: Orang dengan gangguan jiwa, Sikap, Tingkat pengetahuan

\section{ABSTRACT}

A person with mental disorder is someone who experiences disturbances in thoughts, behaviors and feelings that are manifested in the form of a group of symptoms and cause obstacles in carrying out their functions. People with mental disorders are still discriminated against, ridiculed, shunned, ignored, ostracized and considered a disgrace in the community. This treatment is due to the lack of public knowledge of people with mental disorders. This study aims to determine the relationship of the level of knowledge on people's attitudes in people with mental disorders with a descriptive correlation research design. The research sample was 99 respondents taken based on inclusion criteria using cluster sampling techniques. The measuring instrument used was a questionnaire sheet that had been tested for validity and reliability. The analysis used is univariate analysis to determine the frequency distribution and bivariate using chi square test. The results showed that of the 99 respondents who had a good level of knowledge as many as 64 respondents (64.4\%), respondents who had a positive attitude were 55 respondents $(55.5 \%)$. The statistical test results obtained $p$ value $=0,000<\alpha(0.05)$, then Ho is rejected, so it can be concluded that there is a significant relationship between the level of knowledge of people's attitudes towards people with mental disorders. It is recommended for the community to be able to increase knowledge so as to have a positive attitude to people with mental disorders.

Keywords : People with mental disorders, attitude, level of knowledge 


\section{PENDAHULUAN}

Seseorang dikatakan mengalami gangguan jiwa apabila adanya gangguan pada fungsi mental, yang meliputi emosi, pikiran, perilaku, perasaan, motivasi, keinginan, kemauan, daya tilik diri, dan persepsi sehingga mengganggu dalam proses hidup di masyarakat (Nasir \& Muhith, 2011). Pendapat ini sesuai dengan pernyataan yang dikemukakan oleh Keliat, Akemat, Helena, dan Nurhaeni (2011) Gangguan jiwa merupakan sindrom atau pola perilaku yang secara klinis bermakna yang berkaitan langsung dengan distress (penderitaan) dan menimbulkan hendaya (disabilitas) pada satu atau lebih fungsi kehidupan manusia.

WHO (2016) mengatakan sekitar 35 juta orang dengan depresi, 60 juta orang dengan bipolar, 47,5 juta dengan dimensi serta 21 juta orang dari seluruh dunia dengan skizofrenia. Skizofrenia lebih sering terjadi pada laki-laki (12 juta), dibandingkan perempuan (9 juta). Sedangkan Hasil Riset Kesehatan Dasar (Riskesdas) tahun 2018, terjadi peningkatan proporsi gangguan jiwa pada data yang cukup signifikan jika dibandingkan dengan Riskesdas 2013, naik dari 1,7 per mil menjadi 7 per mil. Sedangkan data Dinas Kesehatan (Dinkes) Kota Pekanbaru mengatakan, bahwa pada tahun 2018 jumlah penderita gangguan jiwa terbanyak di penderita gangguan jiwa. Jumlah terbanyak terdapat di wilayah kerja Puskesmas Sidomulyo Rawat Inap (RI) (76 orang) (Dinkes, 2018).

Data jumlah gangguan jiwa saat ini cukup mengkhawatirkan, berdasarkan hasil Riset Kesehatan Dasar (Riskesdas) tahun 2013, dari sekitar 400.000 orang dengan gangguan jiwa, satu diantara 7 orang dengan gangguan jiwa tersebut pernah mengalami penanganan serta perlakuan yang salah seperti pemasungan. Peluang pemasungan tersebut lebih besar pada kelompok yang tinggal di pedesaan atau berasal dari sosial ekonomi bawah.
Salah satu bentuk perlakuan yang salah adalah stigma dan diskriminasi yang lebih besar dari masyarakat disekitarnya dibandingkan individu yang menderita penyakit medis lainnya diantaranya dikeluarkan dari sekolah, diberhentikan dari pekerjaan, diceraikan oleh pasangan, hingga ditelantarkan oleh keluarga, bahkan dipasung serta dirampas harta bendanya (Kemenkes RI, 2014). Mereka sering sekali disebut sebagai orang gila ataupun diberi label negatif oleh masyarakat. Perlakuan ini disebabkan karena ketidaktahuan atau pengertian yang salah dari keluarga atau anggota masyarakat mengenai gangguan jiwa.

Hasil penelitian Asti, Sarifudin, dan Agustin (2016) mengatakan bahwa masyarakat masih memberikan prasangka dan diskriminasi terhadap orang dengan gangguan jiwa mereka sering mendapat cemooh, dijauhi, diabaikan, dikucilkan dan dianggap aib dimasyarakat (87,43\%). Masyarakat masih banyak yang beranggapan buruk terhadap orang dengan gangguan jiwa, masyarakat menganggap orang dengan gangguan jiwa adalah orang yang mengerikan, memalukan, menakutkan, dan aib yang harus disembunyikan. Salah satu penyebabnya karena rendahnya pendidikan serta pengetahuan masyarakat tentang kesehatan jiwa.

Menurut (Funk \& Drew, 2011) rendahnya pengetahuan masyarakat mengenai orang dengan gangguan jiwa berdampak pada pelayanan yang berkualitas rendah dan stigma yang terjadi dalam masyarakat bahwa orang dengan gangguan jiwa itu berbahaya, sehingga menimbulkan banyak diskriminasi, pengucilan, penolakan serta marginalisasi dalam masyarakat, bahkan hingga di pasung.

Pengetahuan akan mempengaruhi sikap masyarakat terhadap orang yang menderita gangguan jiwa. Hasil penelitian Sulistyorini (2013) dengan judul "hubungan pengetahuan tentang gangguan 
jiwa terhadap sikap masyarakat kepada penderita gangguan jiwa di wilayah kerja puskesmas Colomadu 1" bahwa terdapat hubungan yang signifikan antara pengetahuan tentang gangguan jiwa terhadap sikap kepada penderita gangguan jiwa di wilayah kerja Puskesmas Colomadu 1. Semakin baik pengetahuan masyarakat tentang gangguan jiwa, maka semakin positif sikap masyarakat kepada penderita gangguan jiwa.

Penelitian Islamiati, Widianti dan Suhendra (2018) dengan judul Sikap Masyarakat Terhadap Orang dengan Gangguan Jiwa di Desa Kersamanah Kabupaten Garut mengatakan faktor salah satu meningkatnya angka kekambuhan orang dengan gangguan jiwa yaitu sikap masyarakat yang tidak mendukung terhadap adanya orang dengan gangguan jiwa di lingkungannya.

Peneliti melakukan wawancara terhadap 10 orang masyarakat yang berada di wilayah kerja puskesmas Sidomulyo RI pada tanggal 15-17 Mei 2019 mengenai tingkat pengetahuan dengan sikap masyarakat terhadap orang dengan gangguan jiwa. Hasil wawancara yang peneliti lakukan dari 10 orang masyarakat yang di wawancarai terhadap pengetahuannya tentang gangguan jiwa diperoleh hasil bahwa 6 orang mengatakan orang gangguan jiwa adalah orang gila yang harus dihindari karena bisa membahayakan orang lain dan anak-anak dan bisa mengamuk kapan saja seperti bisa melempar barang-barang serta menyakiti warga yang berada di dekatnya. Masyarakat berharap orang gangguan jiwa itu tidak ada di lingkungannya kalau pun ada sebaiknya disingkirkan sedangkan 4 orang lagi mengatakan orang gangguan jiwa itu tidak perlu dimusuhi karena mereka hanya sedang sakit dan membutuhkan pengobatan. Rendahnya tingkat pengetahuan masyarakat ini tentang gangguan jiwa berdampak dengan masyarakat yang masih banyak memiliki pengetahuan rendah tentang orang dengan gangguan jiwa yang ada di lingkungannya.
Selain itu, hasil wawancara yang peneliti lakukan dari 10 orang masyarakat yang di wawancarai terhadap sikap masyarakat pada orang dengan gangguan jiwa 7 orang masyarakat masih memiliki sikap seperti mengucilkan, menghindari bahkan tidak melibatkan dalam kegiatan di masyarakat. Menurutnya tidak ada gunanya memperdulikan orang yang sedang sakit jiwa itu, sedangkan 3 orang masyarakat mengatakan orang gangguan jiwa tidak boleh dimusuhi karena penderita hanya mengalami gangguan berpikir atau stress pada dirinya dan penderita juga manusia yang perlu dukungan dari keluarga, lingkungan untuk proses penyembuhannya.

\section{TUJUAN PENELITIAN}

Tujuan penelitian ini adalah untuk mengetahui hubungan tingkat pengetahuan terhadap sikap masyarakat pada Orang Dengan Gangguan Jiwa (ODGJ).

\section{MANFAAT PENELITIAN}

Hasil penelitian ini diharapkan dapat memberikan sumber informasi dan pengetahuan tentang hubungan tingkat pengetahuan dengan sikap masyarakat terhadap ODGJ.

\section{METODOLOGI PENELITIAN}

Penelitian ini dilaksanakan di wilayah kerja Puskesmas Sidomulyo RI tepatnya di Kelurahan Sidomulyo Barat yang dimulai bulan November sampai dengan Desember 2019. Penelitian ini menggunakan desain penelitian deskriptif korelasi dan pendekatan cross sectional. Populasi penelitian ini adalah seluruh masyarakat Kelurahan Sidomulyo RI. Pengambilan sampel menggunakan teknik cluster sampling dengan 99 responden dengan kriteria inklusi pada penelitian ini adalah bersedia menjadi responden penelitian, perwakilan setiap $\mathrm{KK}$ yang tinggal satu RW dengan orang dengan gangguan jiwa yang berdomisili di Kelurahan Sidomulyo Barat, berusia 26-60 tahun, bisa membaca dan menulis. 
Variabel independen pada penelitian ini adalah tingkat pengetahuan dan variabel dependen adalah sikap masyarakat. Alat pengumpul data yang digunakan adalah kuesioner. Kuesioner tentang tingkat pengetahuan dan kuesioner tentang sikap yang telah dilakukan uji validitas dan reliabilitas, dengan hasil uji validitas $(0,546-0,859)$ dan uji reliabilitas $(\alpha=0,9)$ untuk kuisioner tentang tingkat pengetahuan, dan hasil uji validitas untuk kuisioner pernyataan sikap yaitu $(0,478$ $0,640)$ dan uji reliabilitas $(0,781)$. Analisis data dilakukan secara univariat dan bivariat, analisis bivariat dengan uji ChiSquare. Data disajikan dalam bentuk tabel distribusi frekuensi.

\section{HASIL PENELITIAN}

\section{Analisa Univariat}

Tabel 1

Distribusi karakteristik responden menurut umur, jenis kelamin, dan pendidikan terakhir

\begin{tabular}{llll}
\hline No. & Karakteristik Responden & F & $(\%)$ \\
\hline 1. & Umur Responden & & \\
& Dewasa awal (26-35 tahun) & 23 & 23,2 \\
& Dewasa akhir (36-45 tahun) & 43 & 43,4 \\
& Lansia awal (46-55 tahun) & 31 & 31,3 \\
& Lansia akhir (56-65 tahun ) & 2 & 2,0 \\
\hline 2. & Jenis Kelamin & & \\
& Laki-laki & 15 & 15,2 \\
& Perempuan & 84 & 84,8 \\
\hline 3. & Pendidikan Terakhir & & \\
& SD & 4 & 4,0 \\
& SMP & 5 & 5,1 \\
& SMA & 70 & 70,7 \\
& DIII & 13 & 13,1 \\
& S1 & 7 & 7,1 \\
\hline & Total & 99 & 100,0 \\
\hline
\end{tabular}

Berdasarkan tabel 1 terlihat bahwa sebagian besar karakteritik umur responden berada pada kategori dewasa akhir (36-45 tahun) dengan jumlah 43 orang responden $(43,4 \%)$. Karakteristik jenis kelamin sebagian besar responden berada pada kategori perempuan dengan jumlah 84 orang responden (84,8\%). Karakteristik pendidikan terakhir responden sebagian besar yaitu SMA dengan jumlah 70 orang responden $(70,7 \%)$.

Tabel 2

Distribusi responden berdasarkan tingkat pengetahuan terhadap orang dengan gangguan jiwa

\begin{tabular}{clcc}
\hline No. & Tingkat Pengetahuan & F & $\mathbf{( \% )}$ \\
\hline 1. & Baik & 64 & 64,6 \\
\hline 2. & Cukup & 19 & 19,2 \\
\hline 3. & Rendah & 16 & 16,2 \\
\hline \multicolumn{2}{c}{ Total } & 99 & 100,0 \\
\hline
\end{tabular}

Berdasarkan tabel 2 diperoleh data bahwa distribusi frekuensi responden berdasarkan tingkat pengetahuan didapatkan data bahwa sebagian besar pengetahuan responden adalah baik dengan jumlah 64 responden $(64,6 \%)$.

Tabel 3

Distribusi responden sikap masyarakat pada orang dengan gangguan jiwa

\begin{tabular}{clcc}
\hline No. & Sikap & F & $(\%)$ \\
\hline 1. & Positif & 55 & 55,5 \\
\hline 2. & Negatif & 44 & 44,4 \\
\hline & Total & 99 & 100,0 \\
\hline
\end{tabular}

Berdasarkan tabel 3 diperoleh data distribusi frekuensi responden berdasarkan sikap masyarakat pada orang dengan gangguan jiwa didapatkan bahwa sebagian besar responden dengan sikap positif sebanyak 55 responden $(55,5 \%)$.

\section{Analisa Bivariat}

Tabel 4

Hubungan tingkat pengetahuan terhadap sikap masyarakat pada orang dengan gangguan jiwa

\begin{tabular}{cccccccc}
\hline $\begin{array}{c}\text { Tingkat } \\
\text { Pengeta } \\
\text { huan }\end{array}$ & \multicolumn{9}{c}{$\begin{array}{l}\text { Sikap masyarakat pada } \\
\text { orang dengan gangguan } \\
\text { jiwa }\end{array}$} & Total & $\begin{array}{c}P \\
\text { val } \\
\text { ue }\end{array}$ \\
\cline { 2 - 7 } & \multicolumn{2}{c}{ Positif } & \multicolumn{2}{c}{ Negatif } & & \\
\cline { 2 - 7 } & $\mathrm{N}$ & $\%$ & $\mathrm{~N}$ & $\%$ & $\mathrm{~N}$ & $\%$ & \\
\hline Baik & 51 & 79,7 & 13 & 20,3 & 64 & 100,0 & \\
\hline Cukup & 4 & 21,1 & 15 & 78,9 & 19 & 100,0 & 0,0 \\
\hline Rendah & 0 & 0,0 & 16 & 100,0 & 16 & 100,0 & 00 \\
\hline Total & 55 & 55,6 & 44 & 44,4 & 99 & 100,0 & \\
\hline
\end{tabular}

Berdasarkan tabel 4 diperoleh data bahwa hasil analisis hubungan tingkat pengetahuan masyarakat terhadap sikap masyarakat pada orang dengan gangguan jiwa diperoleh bahwa responden tingkat pengetahuan baik dan sikap positif 
sebanyak 51 responden $(79,7 \%)$, responden dengan tingkat pengetahuan baik dan sikap negatif sebanyak 13 responden (20,3\%). Responden dengan tingkat pengetahuan cukup dan sikap positif sebanyak 4 responden $(21,1 \%)$, responden dengan tingkat pengetahuan cukup dan sikap negatif sebanyak 15 responden (78,9\%). Responden dengan tingkat pengetahuan rendah dan sikap positif sebanyak 0 responden $(0,0 \%)$, responden dengan tingkat pengetahuan rendah dan sikap negatif sebanyak 16 responden $(100,0 \%)$. Hasil uji statistik menggunakan uji chi square diperoleh nilai $p$ value $=0,000<\alpha(0,05)$, maka Ho ditolak, sehingga dapat disimpulkan bahwa terdapat hubungan yang signifikan antara tingkat pengetahuan terhadap sikap masyarakat pada orang dengan gangguan jiwa.

\section{PEMBAHASAN}

\section{Karakteristik responden}

\section{a. Umur}

Berdasarkan penelitian yang telah dilakukan di wilayah kerja Puskesmas Sidomulyo RI tepatnya di Kelurahan Sidomulyo Barat terhadap 99 responden didapatkan sebagian besar umur responden berada pada kategori usia 36-45 tahun sebanyak 43 orang $(43,4 \%)$. Hal ini menunjukkan mayoritas umur responden berada pada rentang kategori dewasa akhir (Depkes RI, 2013). Hal ini dikarenakan responden pada usia dewasa akhir lebih banyak ikut berpartisipasi dalam proses pengisian kuesioner penelitian. Daya tangkap dan pola pikir seseorang terhadap suatu objek akan meningkat seiring dengan bertambahnya usia sehingga pengetahuan yang diperolehnya semakin membaik (Notoatmodjo, 2012).

Nursalam (2012), menyatakan bahwa semakin cukup usia seseorang maka tingkat kematangan dan kekuatan seseorang akan lebih matang dalam berpikir dan bekerja dari segi kepercayaan masyarakat yang lebih dewasa akan lebih percaya dari pada orang yang belum cukup umur tinggi kedewasaannya.

Semakin bertambah usia seseorang maka semakin mudah untuk menganalisis masalah secara alamiah, berpikir secara abstrak dan memecahkan masalah. Selain itu pengalaman seseorang akan sesuatu hal akan mempengaruhi tingkat kematangan seseorang dan mempengaruhi pola pikir akan sesuatu hal.

\section{b. Jenis Kelamin}

Peneliti mendapatkan bahwa sebagian besar responden adalah perempuan sebanyak 84 orang responden $(84,8 \%)$. Hasil penelitian ini sejalan dengan penelitian Astanti (2018) dimana jumlah responden terbanyak adalah responden dengan jenis kelamin perempuan dengan jumlah 27 (54,0\%).

Distribusi responden berdasarkan jenis kelamin dalam penelitian ini mayoritas adalah perempuan dikarenakan pada saat penelitian, peneliti lebih banyak berjumpa dengan responden yang berjenis kelamin perempuan dan responden yang berjenis kelamin perempuan lebih banyak yang bersedia untuk mengisi lembar kuesioner dari pada responden dengan jenis kelamin laki-laki.

\section{c. Pendidikan Terakhir}

Peneliti mendapatkan bahwa sebagian besar pendidikan responden adalah tamatan SMA yaitu 70 responden $(70,7 \%)$ dengan ini menunjukkan tingkatan pendidikan responden dalam kategori tinggi. Pendidikan yang tinggi tentunya akan memberikan pengetahuan yang baik, pendidikan mempengaruhi pola pikir seseorang makin tinggi pendidikan seseorang maka makin mudah seseorang untuk menerima informasi sehingga menambah wawasan pengetahuan seseorang.

Hasil penelitian ini sejalan dengan penelitian Saragih (2013) dengan judul gambaran tingkat pengetahuan dan sikap keluarga tentang perawatan pasien risiko perilaku kekerasan di rumah yang menunjukkan bahwa sebagian besar 
pendidikan responden yaitu SMA sebanyak 17 responden $(51,5 \%)$.

Pendidikan menyangkut seluruh aspek kepribadian manusia seperti hati nurani, nilai-nilai, perasaan, pengetahuan, dan keterampilan. Pendidikan pada hakikatnya akan mencakup kegiatan mendidik, mengajar, dan melatih (Sadulloh, 2012). Pendidikan merupakan salah satu faktor yang mempengaruhi seseorang dalam proses belajar, semakin tinggi pendidikan seseorang maka semakin mudah orang tersebut menerima berbagai informasi dan meningkatkan pengetahuan (Budiman \& Riyanto, 2013).

\section{d. Tingkat pengetahuan masyarakat terhadap orang dengan gangguan jiwa}

Peneliti mendapatkan data bahwa sebagian besar pengetahuan responden adalah baik dengan jumlah 64 responden $(64,6 \%)$. Kategori pengetahuan baik adalah responden mampu menjawab dengan benar 75\%-100\% dari seluruh pertanyaan tentang gangguan jiwa (Wawan \& Dewi, 2010). Hal ini disebabkan karena responden mendapat informasi yang baik tentang gangguan jiwa dari berbagai macam sumber seperti media massa atau pun penyuluhan. Menurut Budiman dan Riyanto (2013), bahwa adanya informasi baru mengenai suatu hal memberikan landasan kognitif baru bagi terbentuknya pengetahuan terhadap hal tersebut.

Hasil penelitian ini sejalan dengan penelitian Yusnipah (2012) dengan judul tingkat pengetahuan keluarga dalam merawat pasien halusinasi di Poliklinik Psikiatri Rumah Sakit Marzoeki Mahdi Bogor menunjukkan bahwa tingkat pengetahuan masyarakat sebagian besar memiliki pengetahuan baik yaitu 58 responden $(57,7 \%)$.

\section{e. Sikap masyarakat pada orang dengan gangguan jiwa}

Peneliti mendapatkan bahwa sebagian besar responden memiliki sikap positif pada orang dengan gangguan jiwa yaitu sebanyak 55 responden $(55,6 \%)$.
Hasil penelitian ini sejalan dengan penelitian Sari (2018) dengan judul tingkat pengetahuan, persepsi dan sikap masyarakat terhadap Orang Dengan Gangguan Jiwa di Kelurahan Rowosari Kota Semarang didapatkan bahwa sebagian besar masyarakat memiliki sikap positif sebanyak 50 orang $(61,0 \%)$ dan 32 orang $(39,0 \%)$ memiliki sikap negatif. Sikap positif yaitu sikap yang menunjukkan penerimaan, mengakui, menyetujui serta melaksanakan normanorma yang berlaku di mana individu itu berada. Sikap merupakan kecenderungan afektif suka tidak suka pada suatu objek tertentu (Hakim, 2012).

Hasil penelitian ini juga didukung oleh penelitian Sulystiorini (2013) dengan judul hubungan pengetahuan tentang gangguan jiwa terhadap sikap masyarakat kepada penderita gangguan jiwa di wilayah kerja Puskesmas Colomadu 1 didapatkan bahwa sebagian besar memiliki sikap positif kepada penderita gangguan jiwa yaitu sebanyak 63 responden (63\%).

\section{Hubungan tingkat pengetahuan terhadap sikap masyarakat pada orang dengan gangguan jiwa}

Hasil uji statistik dengan menggunakan uji alternatif Pearson Chi Square diperoleh nilai $p$ value $0,000<\alpha$ $(0,05)$ berarti Ho ditolak. Hal ini dapat disimpulkan bahwa ada hubungan tingkat pengetahuan terhadap sikap masyarakat pada orang dengan gangguan jiwa.

Hasil penelitian ini memaparkan bahwa sebagian besar responden memiliki tingkat pengetahuan baik dan sikap positif yang baik pula. Tingkat pengetahuan baik responden yang tinggi dikarenakan responden sering mendapatkan informasi mengenai orang dengan gangguan jiwa melalui penyuluhan yang disampaikan oleh pihak Puskesmas dan kader yang terlatih. Hal ini mendukung pernyataan Rahayu (2010) yang menjelaskan bahwa salah satu faktor yang dapat mempengaruhi pengetahuan adalah paparan informasi, karena dengan mendapatkan informasi itu berarti akan 
menambah pengetahuan dan wawasan seseorang.

Sikap positif tinggi pada responden dikarenakan sebagian responden memilki pengetahuan baik, dengan pengetahuan yang baik maka akan membentuk sikap yang positif pula pada seseorang. Sikap positif masyarakat dikarenakan masyarakat sebagian besar adalah tamatan SMA. Hal ini mendukung pernyataan Azwar (2013) bahwa sikap seseorang dipengaruhi oleh beberapa faktor yaitu pengalaman pribadi, pengaruh orang lain yang dianggap penting, pengaruh kebudayaan, media massa, lembaga pendidikan dan lembaga agama serta faktor emosional.

Hal ini sejalan dengan penelitian Sari (2018), bahwa ada hubungan yang signifikan antara pengetahuan dan sikap masyarakat terhadap orang dengan gangguan jiwa ( $p$ value $0,000<\alpha 0,05$ ). Hasil penelitian tersebut menunjukkan bahwa pengetahuan sangat mempengaruhi dalam pembentukan sikap. Hasil penelitian ini didukung oleh penelitian yang dilakukan oleh Yulianti (2016), dengan memperoleh nilai signifikan 0,000 , berarti ada hubungan antara tingkat pendidikan dengan sikap masyarakat terhadap pasien gangguan jiwa.

Tinggi rendahnya pendidikan tentunya akan mempengaruhi sikap seseorang. Makin tinggi tingkat pendidikan seseorang maka semakin tinggi pula sikapnya, sebaliknya semakin rendah tingkat pendidikan seseorang maka sikapnya semakin rendah.

\section{KESIMPULAN}

Penelitian hubungan tingkat pengetahuan terhadap sikap masyarakat pada orang dengan gangguan jiwa di wilayah kerja Puskesmas Sidomulyo RI tepatnya di Kelurahan Sidomulyo Barat terdapat 99 responden, didapatkan hasil karakteristik umur responden berada pada kategori dewasa akhir (36-45 tahun) dengan jumlah 43 orang responden $(43,4 \%)$. Karakteristik jenis kelamin mayoritas responden berada pada kategori perempuan dengan jumlah 84 orang responden $\quad(84,8 \%)$ Karakteristik pendidikan terakhir responden yang terbanyak yaitu tamatan SMA dengan jumlah 70 orang responden $(70,7) \%$ ).

Karakteristik responden berdasarkan tingkat pengetahuan didapatkan hasil bahwa mayoritas pengetahuan responden adalah baik dengan jumlah responden 64 orang responden $\quad(64,6 \%)$. Karakteristik responden berdasarkan sikap masyarakat pada orang dengan gangguan jiwa didapatkan hasil bahwa mayoritas responden memiliki sikap positif sebanyak 55 orang responden $(55,6 \%)$. Hasil uji statistik menggunakan uji alternatif Pearson Chi Square diperoleh nilai $p$ value $=0,000<\alpha(0,05)$, maka Ho ditolak, sehingga dapat disimpulkan bahwa terdapat hubungan yang signifikan antara tingkat pengetahuan terhadap sikap masyarakat pada orang dengan gangguan jiwa.

\section{SARAN}

1. Bagi Perkembangan Ilmu Keperawatan Hasil penelitian ini dapat dijadikan bahan dan pedoman untuk menambah ilmu pengetahuan serta wawasan dan sumber informasi bagi mahasiswa keperawatan tentang gangguan jiwa.

2. Bagi Pihak Puskesmas

Penelitian ini diharapkan bermanfaat sebagai bahan masukan bagi Puskesmas untuk tetap memberikan upaya promotif atau penyuluhan kesehatan tentang kesehatan jiwa yang melibatkan masyarakat.

3. Bagi Mayarakat

Penelitian ini dapat dijadikan sebagai bahan masukan terhadap masyarakat agar memberikan sikap positif kepada orang dengan gangguan jiwa (ODGJ) yang ada dikeluarga maupun di lingkungan masyarakat.

4. Bagi Peneliti Selanjutnya

Sebagai data dasar tentang tingkat pengetahuan masyarakat dari hasil penelitian ini dapat memberikan ide untuk 
penelitian selanjutnya seperti faktor-faktor yang dapat mempengaruhi pengetahuan masyarakat serta faktor-faktor yang mempengaruhi sikap masyarakat pada orang dengan gangguan jiwa lebih spesifik lagi.

\section{DAFTAR PUSTAKA}

Nasir, A., \& Muhith, A. (2011). Dasar dasar keperawatan jiwa. Jakarta : Salemba Medika

Keliat, B.A., Akemat., Helena, N., \& Nurhaeni, H. (2011). Keperawatan kesehatan jiwa komunitas, CMHN (Basic Course). Jakarta : EGC

WHO.

http://www.depkes.go.id/article /print/16100700005/peran-keluargadukung-kesehatan-jiwamasyarakat.html di akses tanggal 25 Mei 2019

Riskesdas, (2018). Data hasil riset kesehatan dasar. Balitbangkes Kemenkes RI.

Riskesdas, (2013). Data hasil riset kesehatan dasar. Balitbangkes Kemenkes RI.

Dinas Kesehatan Provinsi Riau. (2018). http://yankes.kemkes.go.id/assets/do wnloads/UU\%20No.\%2018\%20Th\% 202\%20ttg\%20Kesehatan\%20Jiwa.p df di akses tanggal 25 Mei 2019

Kemenkes RI. (2014). Stop stigma dan diskriminasi terhadap orang dengan gangguan jiwa (ODGJ). Di akses tanggal 12 September 2019

Asti, A.D., Sarifudin, S., \& Agustin, I.M. (2016). Public stigma terhadap orang dengan gangguan jiwa di Kabupaten Kebumen. STIKES Muhammadiyah Gombang

https://doi.org/10.26753/jikk.v12i3.1 66

Funk M, \& Drew N. (2012). Assessing and improve and human rights in mental health and social care facilities. WHO, Geneva, Switzerland

Sulistyorini. (2013). Hubungan pengetahuan tentang gangguan jiwa terhadap sikap masyarakat kepada penderita gangguan jiwa di Wilayah kerja Puskesmas Colomadu 1. Fakultas Ilmu Kesehatan : Universitas Muhammadiyah Surakarta

Islamiati, R., Widianti, E \& Suhendra, I. (2018). Sikap masyarakat terhadap orang dengan gangguan jiwa di Desa Kersamanah Kabupaten Garut. Fakultas Keperawatan : Univeritas Padjadjaran. Vol VI No.2

https://doi.org/10.31311/jk.v6i2.4107

Depkes RI. (2013). Kategori umur. Diperoleh tanggal 09 Januari 2020 dari http://kategori-umur-menurutDepkes.html.

Notoatmodjo, S. (2012). Metodologi penelitian kesehatan. Jakarta : PT Rineka Cipta

Nursalam. (2012). Konsep dan penerapan metodologi penelitian ilmu keperawatan. Jakarta : Salemba Medika

Astanti, D.A (2018). Hubungan tingkat pengetahuan dengan persepsi masyarakat terhadap orang dengan gangguan jiwa di dusun Ketingan Tirtoadi Sleman Yogyakarta. Fakultas Ilmu Kesehatan : Universitas 'Aisyiyah

Saragih, S. (2013). Gambaran tingkat pengetahuan dan sikap keluarga tentang perawatan pasien resiko perilaku kekerasasan di rumah. Program Studi Ilmu Keperawatan : Universitas Indonesia

Sadullah, U. (2010). Pedagogik (Ilmu Mendidik). Bandung : Alfabeta

Budiman \& Riyanto. (2013). Kapita selekta kuesioner pengetahuan dan sikap dalam penelitian kesehatan. Jakarta : Salemba Medika

Wawan \& Dewi. (2010). Teori dan pengukuran pengetahuan, sikap, dan perilaku manusia. Yogyakarta : Nuha Medika

Yusnipah, Y. (2012). Tingkat pengetahuann keluarga dalam merawat pasien halusinasi di 
Poliklinik Psikiatri Rumah Sakit Marzoeki Mahdi Bogor. Fakultas Ilmu Keperawatan : Universitas Indonesia

Sari, N.D. (2018). Tingkat pengetahuan, persepsi daan sikap masyarakat terhadap Orang Dengan Gangguan Jiwa (ODGJ) di Kelurahan Rowosari Kota Semarang. Fakultas Keperawatan : Universitas Muhammadiyah Semarang

Hakim, I. (2012). Internalisasi nilai nilai agama islam dalam pembentukan sikap dan perilaku siswa sekolah dasar islam terpadu al-muttaqin kota tasikmalaya. Jurnal pendidikan agama islam-ta'lim vol.10 no 1 . Tasikamalaya

Rahayu, S.K. (2010). Perpajakan Indonesia : konsep dan aspek formal. Yogyakarta: Graha Ilmu

Azwar, S. (2013). Sikap manusia teori dan pengukurannya. Yogyakarta: Pustaka Pelajar

Yulianti, T.S., Meilina, W., \& Wijayanti, P. (2016). Hubungan tingkat pendidikan dan tingkat pengetahuan tentang kesehatan jiwa dengan sikap masyarakat terhadap pasien gangguan jiwa. Wonogiri. (Vol. 4 No.1). Diperoleh 09 Januari 2020.

https: //doi.org/ 10.37831/jik.v4i1.79 